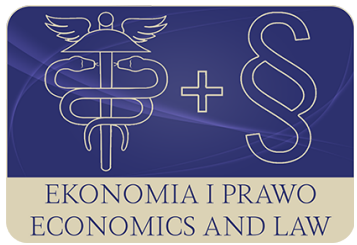

EKONOMIA I PRAWO. ECONOMICS AND LAW

Volume 19, Issue 3, September 2020

p-ISSN 1898-2255, e-ISSN 2392-1625

www.economicsandlaw.pl

ORIGINAL ARTICLE

received 13.03.2020; revised 30.04.2020; accepted 30.09.2020

Citation: Zawadzki, A. (2020). Subsidies in the financial statements of companies listed on the Warsaw Stock Exchange. Ekonomia i Prawo. Economics and Law, 19(3): 585-599. doi:10.12775/EiP.2020.039.

\title{
Subsidies in the financial statements of companies listed on the Warsaw Stock Exchange
}

\author{
ALEKSANDER ZAWADZKI \\ Nicolaus Copernicus University in Torun, Faculty of Economic Sciences and Management, \\ Department of Financial Accounting, ul. Gagarina 13a, 87-100 Toruń, Poland \\ ๑alexzaw@econ.umk.pl \\ (D) orcid.org/0000-0002-1240-4825
}

\begin{abstract}
Motivation: In connection with the growing popularity of using non-returnable public aid, financed both from national and European Union funds among the enterprises, it is worth looking at the quality of financial reporting in this respect. The author's earlier studies showed that companies listed on the Warsaw Stock Exchange (WSE) on the NewConnect market do not fully disclose the impact of the subsidy on their financial standing and results.

Aim: The aim of the paper is an attempt to diagnose the quality of financial statements of public companies listed on the WSE main market in terms of using subsidies as well as confirming the theses included in the paper. The theses refer to compliance with the reporting obligations and the lack of dependence of the disclosure number on the significance of the subsidy amounts in the financial statement.

Results: Both explanatory notes and the management board's report on operations do not include all required disclosures. This is demonstrated by the average as well as the median of the number of disclosures below half of their maximum number. The number of disclosures is not related to the increased significance of the subsidy amounts in the financial statements, which has been confirmed by comparing the entire population of companies under study to a group of companies with the share of subsidies determined as significant. Analysis results for individual company reports as well as the analysis at sectoral level speak in favour of this finding.
\end{abstract}


Keywords: subsidies; financial statement; IAS 20

JEL: M41; K22; H25

\section{Introduction}

In connection with the growing popularity of using non-returnable public aid among the enterprises, financed both from national and European Union funds, it is worth looking at the quality of financial reporting in this field. Polish enterprises adopt provisions of the Polish Accounting Act (1994) and solutions provided by International Accounting Standards (IAS) and International Financial Reporting Standards (IFRS) in this respect. As concerns subsidies, provisions of IAS 20 are applied here (International Accounting Standards Board, 2001). Growing stakeholders' demand for information means that companies, especially those listed on the stock exchange, are forced to present an increasing number of disclosures. Since IAS 20 offers more alternative solutions than Accounting Act (1994), the absence of certain disclosures may lead to a limited comparability of financial statements (Zawadzki, 2014b, p. 322). Besides, IAS 20 defines the minimum scope of disclosures (International Accounting Standards Board, 2001, p. 39):

- the accounting policy adopted for government grants, including the methods of presentation applied in the financial statements;

- the nature and extent of government grants recognised in the financial statements and an indication of other forms of government assistance from which the entity has directly benefited;

- unfulfilled conditions and other contingencies attaching to government assistance that has been recognised.

The author of the present paper in his earlier studies showed that companies listed on the Warsaw Stock Exchange (WSE) on the NewConnect market do not fully disclose the impact of a subsidy on their financial standing and results (Zawadzki, 2014b, p. 321). This paper is a continuation of the author's research in this area and fills the research gap in the field of quality of financial reporting in terms of subsidies. The subjects of the study are annual reports of capital groups listed on the WSE on the main market, made public in 2019. They are prepared based on IFRS regulations, including IAS 20. The paper aims to diagnose the quality of financial statements produced by public companies in the aspect of using the subsidies. The author's earlier studies (Zawadzki, 2014b, p. 318) allowed establishing a minimum number of disclosures in explanatory notes and the management board's report on operations, which let formulate four theses for the purposes of this article: Tl. Financial statements of capital groups do not provide full information on the impact of a subsidy on financial position of a subsidy beneficiary. T2. The number of disclosures in subsidy-related explanatory notes does not depend on the significance of subsidy amounts in the financial statements. T3. The management board's report on operations does not fill the information gap arising in the financial statements. T4. The 
number of disclosures in the management board's report on operations is not dependent on the significance of subsidy amounts in the financial statements. The layout of the paper and the methods adopted enable achieving the goal and confirming the theses.

\section{Literature review}

There has been a large body of research regarding reporting on subsidies by several Polish authors Bartoszewicz et al. (2010), Kędziora (2010), or Lech \& Wszotek-Lech (2011), among the others, took up this topic. The majority of studies emphasize the correctness of subsidy accounting in terms of meeting the reporting requirements imposed by authorities with EU funding opportunities. Other studies however focus on the correctness of recognition in books and presentation of the subsidy usage effects in a financial statement. The author's previous research shows that entities to a very small extent provide information to stakeholders about such considerable events and amounts which significantly limits the comparability of these statements (Zawadzki, 2014a). This topic was tackled by: Kobiela-Pionnier (2012), Osikowicz (2009), Prusak \& Rokita (2017), Wrona \& Żuk (2010; 2011), Zawadzki (2014a), Zwolennik (2017) and Żuk (2011). All the mentioned researchers outline the issues related to the organization of the accounting system in connection with obtaining and spending subsidies. According to Żuk (2011, p. 358), applying the subsidy offset method to the asset value or costs will cause some ambiguities regarding certain items of the report to be clarified or be much smaller. Other solutions as proposed by IAS 20 may be misleading for a stakeholder. Wrona \& Żuk (2010, p. 232) analysed the possibilities of presenting the income from subsidies. They concluded that depending on the internal regulations of entities the income may be presented in two different places of the profit and loss account, as well as can adjust the value of assets that have been financed from a subsidy. According to the authors, the issue of entries in the accounting books and presentation in the financial statement of the subsidies aiming to finance industrial research and/or development work, as well as implementing the research or works results in the entrepreneur's operations, plays an important role for business entities thanks to an option of using EU subsidies on a large scale (Wrona \& Żuk, 2011, p. 198). Prusak \& Rokita (2017, p. 184) noticed that cash recognition of subsidies in revenues may generate uncertainties as to the presentation of a true and reliable image of the enterprise in the financial statements and the usefulness of included information in making decisions by external users, as for example the financial result of one period may be overestimated, and subsequent periods can be underestimated, or vice versa. Zwolennik (2017, p. 55) points out the special role of accounting policy in the area of the correct recognition and presentation of subsidies. According to the principles of accounting policy beneficiaries of subsidies have to meet special requirements concerning presentations related to a specific character of accounting for subsidies received, 
including the scheme of recognizing the subsidy in the accounting books, the moment when the subsidy is classified as income, as well as the method of separating the accounting records. Having access to the financial statements of entities benefiting from subsidies, Kobiela-Pionnier (2012, p. 88) examined 62 entities for errors being made. Only 9 entities avoided significant errors. The most common incorrectness was subsidy revenues not settled in a timely manner, the omission of subsidies or other forms of public aid in reporting, or double recognition of revenues from the subsidy in the cash flow statements.

Foreign authors most often focused on the problems of implementing IAS 20 in the accounting regulations for a given country. Hlinovsky $(2019$, p. 61) underlines transparency of the use of subsidies in enterprises dealing with air transport. As Hlinovsky (2019) finds in his study the surveyed enterprises do not adopt one standard for the presentation of subsidies; the entities present subsidy amounts without explanatory notes, also data are presented in various parts of the financial statement given a different level of detail. The findings confirm the author's conclusions from previous and current research. Russian authors have similar insights. According to Klychova \& Nurieva (2015, p. 27), the multiplicity of solutions that can be applied as authorized by IAS 20 may lead to incomparability of financial statements for various enterprises. Also Muthupandian (2009, p. 11) indicates that the diversity of solutions proposed by IAS 20 may result in presenting unreliable data in the financial statements. Different valuation bases, e.g. fixed assets may prevent comparison of financial statements.

\section{Methods}

The following research methods were applied in the study: literature analysis and criticism; document content analysis; analysis, synthesis and classification of subsidy disclosures, as well as statistical methods. The study resources consist of financial statements of the capital groups as listed on lst January 2018 on the WSE, which presented their financial statements for the year 2018. The data comes from the WSE website in the section related to company reports. To filter annual reports, in the 'report type' section, just 'report type: annual' was selected. Only consolidated financial statements of capital groups were qualified for the study, due to the obligation to prepare these reports following the IFRS. Because of the special character of business activity of financial entities (banks, insurance companies, investment funds, stock exchanges, leasing factoring etc.), the study excluded groups whose three-digit sector code began with the number one, according to the sector breakdown applicable on the WSE. Then, individual elements of the annual report file were reviewed in the aspect of disclosing the amounts related to subsidies in the reports. For this purpose, the study required machine search using the phrase 'dotac*' or 'dofinan*'. Whenever PDF files have been blocked for machine search the reports were manually reviewed. As the number of sector codes operating on the WSE was large, sectors were 
aggregated to a two-digit level, thus reducing the number of enterprise classes to 32. Subsequently, the qualified financial statements have been verified from the point of view of valuable data related to subsidy value data and disclosures required by IAS 20 in the annual report on subsidies, split into explanatory notes and management board report on operations. The data resulting from these reports for each company were entered into the specifically designed evaluation sheet, which became the basis for calculations using descriptive statistics tools, and starting point for verification of the theses made in the introductory part of this paper. Additionally, to confirm theses T2 and T4, the Pearson correlation coefficient was calculated. All calculations were made using IBM SPSS Statistics version 25.

\section{Results}

\subsection{Characteristics of the research sample}

The analysis of data collected in the evaluation sheet indicated that among 244 consolidated financial statements the aspect of subsidies appeared in 145 annual reports, which constitutes $59.4 \%$ of the total number of entities selected for the study. Taking into account the sum of subsidy shares in the balance sheet and revenues, the sectors where the involvement of subsidies in financing the company activities was the largest, were those sectors in which this share was greater than $2 \%$. These are sectors related to energy and green energy, drug production, biotechnology with a share from $10 \%$ to $37 \%$. Another group consisted of the following sectors: groceries and fast-food products, computers and electronics, recycling, software, medical equipment and materials with a share from $5 \%$ to $10 \%$. The sectors with the smallest subsidy share in this group were: builders and building materials; radio, television, advertising, internet portals, media; hospitals and clinics; other trade and services; equipment and means of transport with a share from $2 \%$ to $5 \%$. However, the entire population of 145 companies was accepted for further analysis because of two aspects: among the companies outside the sectors listed above were companies characterized by:

- higher than 2\% individual share of subsidies in revenues and balance sheet total;

- a large number of subsidy disclosures, despite their small share in revenues and balance sheet total.

\subsection{Analysis of the number of disclosures in the explanatory notes}

Pursuant to the provisions of IAS 20, all entities are required to inform the stakeholders about the recognition and presentation of subsidies in the fi-

\footnotetext{
${ }^{1}$ Significance level conventionally accepted in accounting policy.
} 
nancial statements. In the studied group, 110 companies fulfilled this obligation, representing $75.9 \%$ of the entire population. The timely manner of subsidy recognition was determined by 96 companies (66.2\%). In the course of conducting the analysis of entries included in explanatory notes, some groups of disclosures were classified according to the following features:

- purpose of the subsidy;

- explanation of deferred income from subsidies;

- specification of the subsidy source;

- data on the historical cost and redemption of the fixed assets acquired from subsidies;

- data on the amount of costs covered by a subsidy;

- contingent liabilities arising from subsidy agreements;

- data about cash at bank collected in the subsidy accounts;

- information on provisions for the possible return of subsidies;

- data on the amounts of ineligible expenditure.

As the analysis of annual report content of all 145 companies shows from the point of view of the information provided, the following types dominated: the source and purpose of the subsidy, $54.5 \%$ and $66.2 \%$, respectively, as well as explanations concerning deferred income from a subsidy equal $62.1 \%$ of the surveyed companies. Other significant disclosures relating to the initial value and redemption of fixed assets acquired from subsidies, the amount of costs covered by a subsidy, contingent liabilities arising from subsidy agreements, the amount of cash in the subsidy account or the amount of ineligible expenditure did not exceed $30 \%$ of the companies surveyed. Detailed data for these disclosures are presented in chart 1 (see data for 145 companies). Moreover, as many as 54 entities (37.2\%) did not indicate the source of the subsidy. Such a low percentage of disclosures could follow the fact that in the entire population of 145 companies, there were entities with an insignificant share of subsidies in the annual report (below 2\% of the balance sheet total or the amount of deferred income). The results regarding the number of disclosures in companies with significant subsidy share (the share of subsidies in the balance sheet total or revenues greater than 2\%) compared to all companies surveyed are also presented in chart 1 . For the most part, except for detailed information on fixed assets and the purpose of the subsidy, the number of disclosures among companies with a significant share of subsidies in the financial statements was higher. Positive differences ranged from about $26 \%$ for disclosures on the source of the subsidy and clarifications regarding deferred income, through 33\% and 36\%, respectively, for the data concerning the amounts accumulated in the subsidy account and the amounts of costs covered by the subsidy, up to $51 \%$ and $56 \%$ respectively, in the case of information on contingent liabilities and amounts of ineligible expenditure under subsidy-financed projects. In a narrower group of entities, distinctly fewer disclosures were related to the purpose of the subsidy (by as much as 64\%). This may be caused by the fact that this is not strictly financial information. Therefore, companies belonging to this 
group do not include this type of data in the explanatory notes, shifting this information to the management board's report on operations. The above-mentioned observations allowed formulating research theses $\mathrm{T} 1$ and $\mathrm{T} 2$ presented in the introduction to this paper.

Table 1 presents the results of calculations in the aspect of disclosure frequency in the explanatory notes and the management board's report on operations in the entire population surveyed. The average number of disclosures included in the notes is 5 (5.04) out of 12 possible disclosures, although none of the companies presented their maximum number. The median of these disclosures, also equal to five, indicates that half of the companies present no more than 5 disclosures and the other half no less than 5. Standard deviation equal to 2.664 with the average equal to 5 indicates average dispersion of the number of disclosures. This may be caused by the fact that IAS 20 specifies some disclosures as mandatory, while some other are defined in too broad a manner and treated as discretionary by companies. The number of companies exposing more than 5 disclosures equals 68 (46.9\%). The most numerous group consists of companies whose number of disclosures in the notes is 7 (the mode). Notably, 11 companies did not disclose any information about subsidies in this part of the annual report, despite showing the subsidy amounts in the balance sheet or profit and loss accounts. The above results confirm the research thesis Tl. Both the average and the median as well as the mode indicate that companies listed on the WSE and preparing financial statements in the part on subsidies based on IAS 20, do not provide complete information about the impact of the subsidy on the financial and material situation of a beneficiary of the subsidy.

Analysis of values of the first $(\mathrm{Ql})$ and third (Q3) quartile confirms this indication: $25 \%$ of companies present no more than 3 disclosures, but even more importantly, $75 \%$ of companies present no more than 7 out of 12 possible disclosures.

A comparison of the entire population surveyed with the results of a narrowed group of entities supports the thesis suggesting that the number of disclosures in the explanatory notes does not depend on the significance of the subsidy amount in the financial statement. The number of disclosures in the narrowed group was more diverse. For testing the dependence of the disclosure numbers on the share of subsidy amounts in the financial statement, the Pearson linear correlation coefficient has been calculated for the entire population $\left(r_{145}\right)$ and for entities in which the share of subsidies in individual elements of the financial statement was higher than $2 \%\left(r_{42}\right)$. The values of correlation coefficients calculated for two variables: the sum of subsidy shares in the financial statement and the number of disclosures in the notes, were $r_{145}=0.145$ and $r_{42}=0.100$, respectively. Both coefficient values mean that linear dependence is absent, thus confirming the thesis that within a population studied the number of disclosures in the notes is not dependent on the significance of the amounts in numerical part of the financial statement. 


\subsection{Analysis of the number of disclosures in the management report}

Since the approach of the management board's reports on operations differs a little, the analysis of their content shows a smaller number of disclosure types in the context of projects co-financed from the subsidy. They were included in the following groups:

- general information on projects co-financed from the subsidies;

- the amounts of subsidies;

- nature and purpose of the subsidy;

- information on assets acquired under the subsidy;

- information on reimbursement of costs covered by subsidies;

- information on depreciation covered by the subsidy.

The analysis of the number of disclosures in the entire group under study showed that information on subsidies in the management board's reports on operations did not show up in over half of surveyed companies (52\%). Most often the information provided was generally concerning projects co-financed from subsidies (48\%), the information presenting the amount of subsidy (40\%) and the purpose of subsidy (32\%). The information on the purchase of assets and reimbursement in projects ( $28 \%$ and $15 \%$, respectively) was considered important by less than $1 / 3$ of companies. It allows concluding that the management board's report on operations does not fill the information gaps resulting from the explanatory notes to the financial statements.

The comparative analysis within the same group of disclosures in the management board's reports on operations, limited to entities in which subsidies represented significant amounts (42 companies), reveals noticeable differences, presented in chart 2. For all identified disclosures their percentage in this group is much higher. This is particularly true for the general information on subsidies (67\%), the amounts of subsidies received (57\%) as well as the nature and purpose of subsidies (62\%). This finding confirms the assumption made in point 4.2. that some non-financial information is moved from explanatory notes to the management board's report on operations. The biggest differences in the percentage of disclosures, in favour of a group of 42 companies, accounted for the information on refunded costs (120\%), the nature and purpose of the subsidy (91\%), and the amount of depreciation covered by the subsidy (73\%). Discrepancies in the percentage of general information disclosures on subsidies and the amount of subsidies were also significant and amounted to $40 \%$ and $43 \%$, respectively. The above findings allow formulating research theses T3 and T4 presented in the introduction to this paper.

The analysis of table 1 containing data related to disclosures in the management board's report on operations confirms the thesis T3. In the entire surveyed group, the average of disclosures amounts to 1.76 out of 6 possible disclosures. Half of the surveyed companies disclose no more than 2 facts on subsidies. In the studied population of 145 entities only two presented the maximum number of disclosures, while as many as 61 did not provide any information on this 
subject, hence the mode value equals zero in this group. The standard deviation value slightly exceeding the average value indicates a very large dispersion of the number of disclosures, which means that companies have different approaches to enter the information on subsidies in the management board's report. Placing the information on the subsidies in this part of the annual report is discretionary. The results Q3 also confirm T3 thesis: $75 \%$ of the study group presents no more than 3 out of 6 possible disclosures.

To check the dependence of the number of disclosures in the management board's report on the share of the subsidy amounts in financial statements, the Pearson linear correlation coefficient was calculated for the entire surveyed population $\left(r_{145}\right)$ and for entities in which the share of subsidies in particular components of the financial statements was higher than $2 \%\left(r_{42}\right)$. The value of correlation coefficients calculated for two variables: the sum of subsidy shares in the financial statements and the number of disclosures in the notes was $r_{145}=0.274$ and $r_{42}=0.234$, respectively, with $r_{145}$ determined as being significant. Taking into account the coefficient values, one can conclude that the dependency has only a weak linear growth relation which, in the author's opinion, confirms the thesis that in the examined population the number of disclosures in the management board's report is not dependent on the significance of the subsidy amounts in the numerical part of the financial statements.

\subsection{Sectoral disclosure analysis}

Due to a division of the surveyed population into sectors in section 4.1 of this study, the analysis of disclosures by sector was provided. The average number of disclosures in the explanatory notes and additional information (AI) as well as in the management board's report (MBR) is presented in table 2. In the table 2 , sectors whose sum of an average number of disclosures oscillates around 7 are prevailing. Also the median of this parameter amounting to 6.9 disclosures shows a similar value. Six sectors out of 32 are characterized by a relatively high sum of average disclosures. These are: 73 - drugs production, 62 - daily use articles, 75 - biotechnology, 81 - telecommunication, 31 - basic and specialist chemistry, 21 - extraction and production of fuels and gas. The number of these disclosures is 10 or 11 which compared to the maximum number of total disclosures (17) varies between $58.8 \%$ and $64.7 \%$. Importantly, within these six sectors there is a large variation in the share of subsidy amounts in the financial statements (from $0.02 \%$ to $29.8 \%$ ). Other sectors above the median also reveal a diversified average share of subsidy amounts in the financial statements (from $0.1 \%$ to $10.2 \%$ ). Among the sectors below the median of the average number of disclosures a large diversity of the amounts of subsidies appears. Examples of industries are as follows: 82 - software, and 61 - groceries with fast-food products, computers and electronics, in which a significance of average subsidy amounts does not correspond to the average number of disclosures, which falls 
below the median. The sector analysis also confirms the veracity of theses $\mathrm{T} 2$ and $\mathrm{T} 4$.

\section{Conclusion}

The paper attempts to diagnose the quality of financial statements in terms of using the subsidies in public companies. Unfortunately, the theses T1 and T2 regarding disclosures in the notes have been confirmed. Neither the additional information, nor the explanatory notes contain the disclosures postulated by the author. This is demonstrated by the average and median number of disclosures falling below half of their maximum number. The number of disclosures is not dependent on the increased significance level of the amounts recognised in the financial statements; this fact being confirmed by a comparative analysis of the entire surveyed population and a group of companies in which the share of subsidies was defined as significant. Results of the report analysis for individual company as well as the sector analysis speak in favour of this finding. Similarly, the theses T3 and T4 regarding the management board's report on operations were confirmed. The median number of disclosures equalled two with a maximum of six, and in particular the mode at level zero, confirmed that the management board's report does not fill the information gap arising in the financial statements. As in the case of T2, the number of disclosures in this part of the annual report does not depend on the share of subsidy amounts in the report. The question about the reason for such a situation remains open. According to the author, relatively laconic IAS 20 instructions regarding the range of the subsidy disclosures are the main obstacle. Future studies will focus on the stakeholder perceptions of this problem and persons who prepare the information in question. Also statutory auditor's opinion in this respect should not be considered as insignificant.

\section{References}

Bartoszewicz, A., Cygańska, M., \& Lelusz, H.M. (2010). Wybrane problemy ewidencji wykorzystania środków unijnych na przykładzie Regionalnego Ośrodka Europejskiego Funduszu Społecznego. Zeszyty Teoretyczne Rachunkowości, 58(114).

Hlinovsky, L. (2019). Transparency and application of IAS 20 by the European air navigation services providers. Český finanční a účetní časopis, 1. doi:10.18267/j.cfuc.526.

International Accounting Standards Board. (2001). International accounting standard 20: accounting for government grants and disclosure of government assistance. Retrieved 18.02.2020 from http:/ / eifrs.ifrs.org.

Kędziora, H. (2010). Wyodrębniona ewidencja operacji w projektach finansowanych ze środków unijnych z wzorcowym planem kont. Gdańsk: ODDK. 
Klychova, G.S., \& Nurieva, R.I. (2015). Adapting IAS 20 accounting for government grants and disclosure of government assistance for use in domestic accounting. International Accounting, 4(346).

Kobiela-Pionnier, A. (2012). Polityka rachunkowości w zakresie pomocy publicznej oraz jej wpływ na jakość sprawozdania finansowego. In D.A. Mikulska (Ed.), Polityka rachunkowości jednostki a jakość sprawozdania finansowego: wybrane aspekty. Lublin: KUL.

Lech, M., \& Wszołek-Lech, D. (2011). Jak prawidtowo rozliczyć projekt realizowany w ramach Programu Operacyjnego Kapitat Ludzki. Gdańsk: ODDK.

Muthupandian, K.S. (2009). IAS 20 accounting for government grants and disclosure of government assistance: a closer look. The Management Accountant, 44(8).

Osikowicz, M. (2009). Rachunkowe i podatkowe aspekty ewidencji dotacji z funduszy strukturalnych. Zeszyty Naukowe Uniwersytetu Ekonomicznego w Krakowie, 796.

Prusak, A., \& Rokita, S. (2017). Projekty badawczo-rozwojowe dofinansowywane ze środków unijnych w księgach rachunkowych: wybrane problemy. Przedsiębiorczość i Zarządzanie, 18(12).

Ustawa z dnia 29 września 1994 r. o rachunkowości [Accounting Act of September 29, 1994] (Dz.U. $1994 \mathrm{nr} 121$ poz. 59l) (Poland).

Wrona, M., \& Żuk, K. (2010). Przychody z tytułu dotacji unijnych w sprawozdaniu finansowym przedsiębiorstwa. Zeszyty Teoretyczne Rachunkowości, 54(110).

Wrona, M., \& Żuk, K. (2011). Ujęcie w księgach rachunkowych i w sprawozdaniu finansowym dotacji z Programu Operacyjnego Innowacyjna Gospodarka Działanie 1.4-4.1 „Wsparcie Projektów Celowych oraz Wsparcie Wdrożeń Wyników Prac B+R". Roczniki Ekonomii i Zarządzania, 3.

Zawadzki, A. (2014a). Rola informacji dodatkowej i sprawozdania zarządu w sprawozdawczości jednostek korzystających z dotacji unijnych na podstawie spółek notowanych na New Connect: wyniki badań. In Z. Głodek, \& M. Trocka (Eds.), Wybrane aspekty z rachunkowości i sprawozdawczości finansowej. Gorzów Wielkopolski: PWSZ.

Zawadzki, A. (2014b). Standardy sprawozdawczości w zakresie środków unijnych w polskich spółkach notowanych na NewConnect. Prace Naukowe Uniwersytetu Ekonomicznego we Wroctawiu, 329. doi:10.15611/pn.2014.329.34.

Zwolennik, A. (2017). Księgowe ujęcie dotacji unijnych w aspekcie prawa bilansowego i Międzynarodowych Standardów Rachunkowości. Studia Ekonomiczne: Gospodarka, Spoteczeństwo, Środowisko,1(1).

Żuk, K. (2011). Zmiany zasad rachunkowości w zakładach pracy chronionej. Zeszyty Teoretyczne Rachunkowości, 60(116). 


\section{Acknowledgements}

Author contributions: author has given an approval to the final version of the article.

Funding: this research was funded by the Nicolaus Copernicus University in Torun, Faculty of Economic Sciences and Management statutory sources. 


\section{Appendix}

Table 1.

Analysis of disclosure frequency in a surveyed population (145 companies)

\begin{tabular}{|c|c|c|c|c|}
\hline \multirow{2}{*}{\multicolumn{2}{|c|}{ Specification }} & \multicolumn{3}{|c|}{ Disclosure number } \\
\hline & & explanatory notes & management board's report & sum of disclosures \\
\hline \multicolumn{2}{|c|}{ number of important data } & 145 & 145 & 145 \\
\hline \multicolumn{2}{|c|}{ number of missing data } & 0 & 0 & 0 \\
\hline \multicolumn{2}{|c|}{ average } & 5.04 & 1.76 & 6.80 \\
\hline \multicolumn{2}{|l|}{ median } & 5.00 & 2.00 & 6.00 \\
\hline \multicolumn{2}{|c|}{ mode } & 7 & 0 & 4 \\
\hline \multicolumn{2}{|c|}{ standard deviation } & 2.664 & 1.792 & 3.874 \\
\hline \multicolumn{2}{|c|}{ variance } & 7.095 & 3.212 & 15.008 \\
\hline \multicolumn{2}{|c|}{ minimum } & 0 & 0 & 0 \\
\hline \multicolumn{2}{|c|}{ maximum } & 11 & 6 & 16 \\
\hline \multirow{3}{*}{ quartile } & 25 & 3.00 & 0.00 & 4.00 \\
\hline & 50 & 5.00 & 2.00 & 6.00 \\
\hline & 75 & 7.00 & 3.00 & 10.00 \\
\hline
\end{tabular}

Notes:

In the explanatory notes three disclosures out of accounting policy were also included.

Source: Own preparation. 
Table 2.

Sectoral average of the disclosure number

\begin{tabular}{|c|c|c|c|c|}
\hline $\begin{array}{l}\text { Sector } \\
\text { code }\end{array}$ & Sector name & $\begin{array}{l}\text { Sum of the average } \\
\text { of subsidies } \\
\text { in the liabilities } \\
\text { and total revenues } \\
\text { (in \%) }\end{array}$ & $\begin{array}{l}\text { Sectoral average } \\
\text { of the disclosure } \\
\text { number in explana- } \\
\text { tory notes }\end{array}$ & $\begin{array}{l}\text { Sectoral average } \\
\text { of the disclosure } \\
\text { number in manage- } \\
\text { ment board's reports }\end{array}$ \\
\hline 21 & $\begin{array}{l}\text { extraction and production of fuels } \\
\text { and gas }\end{array}$ & 1.01 & 7.0 & 3.0 \\
\hline 22 & energy and green energy & 10.17 & 6.5 & 2.8 \\
\hline 31 & basic and specialist chemistry & 1.23 & 8.4 & 2.0 \\
\hline 32 & coal and metal mining & 0.18 & 3.5 & 1.0 \\
\hline 33 & metallurgy & 1.04 & 5.4 & 2.9 \\
\hline 35 & plastics & 0.95 & 6.3 & 0.8 \\
\hline 36 & wood, paper and packaging & 0.92 & 4.3 & 0.7 \\
\hline 37 & recycling & 6.79 & 5.5 & 2.3 \\
\hline 41 & builders and building materials & 2.02 & 4.1 & 1.2 \\
\hline 42 & equipment and means of transport & 4.23 & 5.1 & 2.5 \\
\hline 43 & transport & 0.25 & 1.5 & 3.0 \\
\hline 44 & $\begin{array}{l}\text { articles: electrical, metallurgy } \\
\text { and chemicals }\end{array}$ & 0.64 & 4.0 & 2.0 \\
\hline 45 & enterprise services & 0.51 & 5.0 & 2.0 \\
\hline 51 & food and drinks & 1.47 & 5.4 & 0.6 \\
\hline 52 & clothing, footwear, cosmetics & 1.14 & 5.0 & 1.1 \\
\hline 53 & $\begin{array}{l}\text { furniture, carpets, household } \\
\text { appliances }\end{array}$ & 0.14 & 5.8 & 1.0 \\
\hline 54 & auto parts & 0.33 & 6.0 & 1.5 \\
\hline 61 & $\begin{array}{l}\text { groceries and fast-food products, } \\
\text { computers and electronics }\end{array}$ & 5.99 & 2.0 & - \\
\hline 62 & daily use articles & 0.02 & 7.0 & 4.0 \\
\hline 63 & $\begin{array}{l}\text { hotels, restaurants and travel } \\
\text { agencies }\end{array}$ & 0.01 & 2.5 & - \\
\hline 64 & $\begin{array}{l}\text { radio, television, advertising, } \\
\text { internet portals, media }\end{array}$ & 2.07 & 4.1 & 1.4 \\
\hline 65 & computers games & 0.39 & 6.0 & - \\
\hline 66 & internet commerce & 0.11 & 7.0 & - \\
\hline 69 & other trade and services & 2.46 & 5.0 & 2.0 \\
\hline 71 & hospitals and clinics & 2.24 & 2.5 & 0.5 \\
\hline 72 & medical equipment and materials & 8.85 & 6.0 & 2.5 \\
\hline 73 & drugs production & 29.75 & 7.3 & 4.0 \\
\hline 74 & drugs commerce & 0.00 & 4.0 & - \\
\hline 75 & biotechnology & 37.18 & 7.3 & 3.8 \\
\hline 81 & telecommunication & 0.20 & 7.5 & 3.0 \\
\hline 82 & software & 8.13 & 4.3 & 1.1 \\
\hline 83 & new technologies & 0.01 & - & - \\
\hline
\end{tabular}

Source: Own preparation. 


\section{Chart 1.}

Schare of subsidy disclosures with significant subsidy amounts (42) in additional information and explanatory notes compared to all companies under study (145) (in \%)

data on the amounts of ineligible expenditure

information on provisions for the possible return of subsidies,

data about cash at bank collected in the subsidy accounts

contingent liabilities arising from subsidy agreements

data on the amount of costs covered by a subsidy

data on the historical cost and redemption of the fixed assets

specification of the subsidy source

explanation of deferred income from subsidies

purpose of the subsidy

number of companies (42)

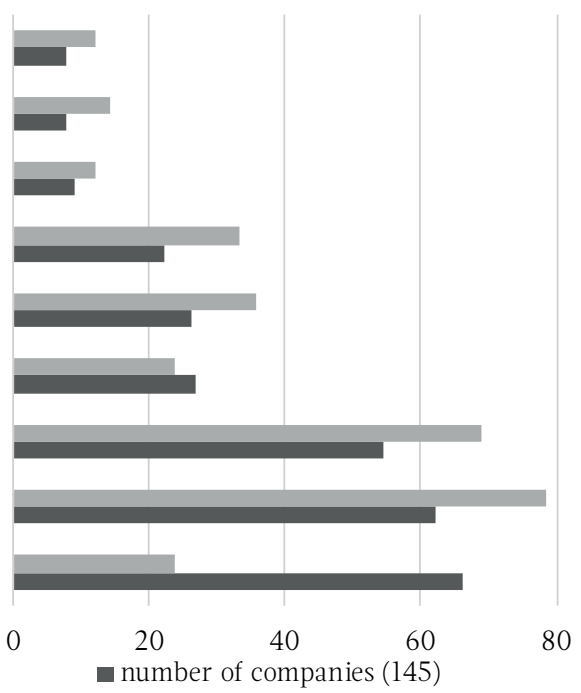

Source: Own preparation.

\section{Chart 2.}

Share of subsidy disclosures with significant subsidy amounts (42) in the management board's reports on operations compared to all companies under study (145) (in \%)

information on depreciation covered by the subsidy

information on reimbursement of costs covered by subsidies

information on assets acquired under the subsidy

nature and purpose of the subsidy

the amounts of subsidies

general information on projects co-financed from the subsidies

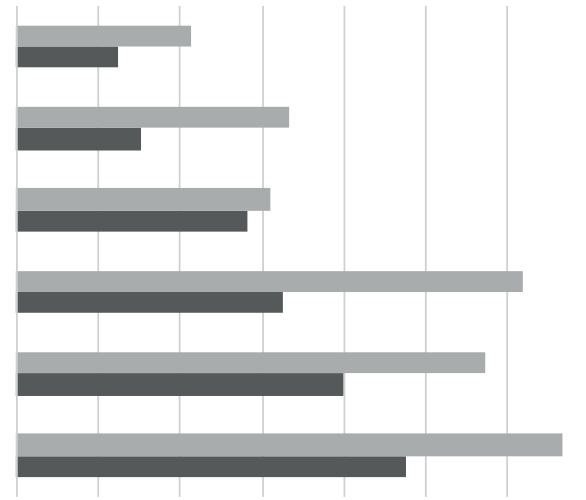

number of companies (42)

$\begin{array}{llllllll}0 & 10 & 20 & 30 & 40 & 50 & 60 & 70\end{array}$

- number of companies (145)

Source: Own preparation. 
